\title{
Tax Treatment Of U. S. Companies Participating In The Maquiladora Industry: Recent Developments Involving The Intergovernmental Agreement On Transfer Pricing And Other Issues
}

\author{
Anita Isley, (E-mail: acisley@email.msn.com), University of North Carolina, Greensboro \\ Art Cassill, (E-mail: acassill@erlon.edu), Elon University \\ Nancy L. Cassill, (E-mail: Nancy_Cassill@ncsu.edu), North Carolina State University
}

\begin{abstract}
The relationship between U.S. companies and Mexican maquiladoras has been evolving for more than thirty years. The original advantages of lower taxes, cheaper labor, quick delivery and special tariff treatments enabled U.S. companies to increase cost-effectiveness and remain competitive worldwide. The arrangement also brought employment opportunities and prosperity to the border region of Mexico. Over time, however, many of the original advantages for both the United States and Mexico have either eroded or disappeared completely. As political and economic changes have occurred, so have changes within the maquiladora industry. In addition, the maquiladoras now face increasing competition from other foreign countries for U.S. business once reserved for the maquiladoras. This paper will examine these issues and the implications of recent changes for both the maquiladora industry and for the U.S. companies who use their services.
\end{abstract}

\section{Background}

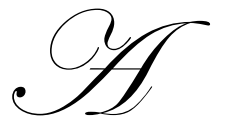

maquiladora is a Mexican company, generally a wholly owned subsidiary of a U.S. company, that provides assembling and manufacturing services to the U.S. related party. Under Mexican law, maquiladoras are generally exempt from customs duties on inventory consigned by the U.S. related party and exempt from Mexican asset taxes on machinery and equipment. Originally located primarily along the U.S.-Mexico border, the operations process imported materials or commodities for re-export to the U.S. The name "maquiladora" comes from the Spanish term "maquila", which is "the miller's corn" or payment in corn that the miller kept for his services.

\section{Industry Evolution}

The foundation of the maquiladoras (often shortened to "maquila") was laid in the northwestern part of Mexico in an area known as the "Zona Libre" or free zone. The official Mexican import policies of high tariffs, import permits and restriction on foreign investment were not followed in this area due to the difficulties of enforcing them. U.S. trade and investment was, for the most part, unrestricted in the area. These early businesses, using inputs from the U.S., set the stage for the development of the maquilas. A contributing factor was the end of the Bracero program by the U.S. in 1964 (Brouthers 37). The program had allowed Mexican workers to enter the U.S.

Readers with comments or questions are encouraged to contact the authors via email. 
temporarily, work on U.S. farms, and return to Mexico at the end of the season. The formal creation of the maquiladoras began with Mexico's Border Industrialization Program of 1966 (Martinez 1). Under this program, raw materials were sent to Mexican border towns and placed in bond. The bond served as a guarantee that the goods would be exported within a required period of time. Permanent importation required that duties be paid on items when they were imported. In bond, or temporary importation, permitted the goods to be imported duty-free. The maquiladora arrangement was one of the limited ways to qualify for temporary importation. The materials were then processed in Mexico and exported to the U.S. with U.S. Customs collecting the duty on the value added. It is important to note that the U.S. government has not passed any legislation that exclusively affects or promotes maquiladoras in Mexico. However, some say the U.S tariff laws passed in 1963 contributed to the development of maquiladora expansion by imposing only a value-added tax on imported items produced by such operations. Some products qualified for reduced tariffs while others were totally exempt.

Before the expansion of the maquila program, direct investment in Mexico required complex governmental approval, 51\% Mexican ownership and often required a percentage of local content (Brouthers 38). Export was difficult due to the country's import permits and high tariffs, which often exceeded $20 \%$ of product value (Brouthers $37)$.

\section{Maquiladora Decree}

The passage of the 1972 maquiladora law marked the beginning of rapid expansion for the maquilas. The new law permitted maquiladoras throughout Mexico, except in densely populated cities. The decree further enhanced the appeal of the maquiladoras to U.S. businesses by offering the following advantages (Sinclair 1):

- $\quad 100 \%$ foreign ownership by U.S. persons allowed.

- $\quad$ Duty-free importation of raw materials, supplies, and machinery

- $\quad$ Customs duty limited to the portion of value added in Mexico. There was no Mexican duty if the goods were re-exported to the country of origin.

- $\quad$ Labor costs considerably lower than in the U.S.

- $\quad$ Operation with no ownership of assets. The maquiladoras have no inventory or fixed assets, thereby eliminating most asset tax.

- $\quad$ Operation as a cost center. The typical operating cycle was:

$>$ Maquilas received material from foreign parents.

$>$ Value added to the material in the form of labor, overhead and Mexican material, in the fabrication of final products.

$>$ Import taxes were paid over the value added (=final product total cost - temporarily imported materials cost) when products were shipped out of the country.

$>$ Maquiladora invoiced foreign parent or client for operating cost plus a small percentage for profit, usually between $1-5 \%$ of operating costs.

Lower wages enticed many American firms to move some aspects of their manufacturing to the maquiladoras, especially those whose operations were labor-intensive. The dominant businesses were electrical assembly and apparel plants and together, they comprised 71\% of total maquila employment by 1979 (Brouthers 38).

\section{Cost Center vs. Profit Center}

Prior to amending its Income Tax Laws in 1992, Mexico allowed maquiladoras to operate as cost centers rather than profit centers (Gongalez-Bendiksen 37). Most were structured so as to be rendering a service rather than selling a product. They received materials from their U.S. parent company on consignment for processing and were typically paid the full amount of their operating expenses plus a percentage. As a result, they paid virtually no Mexican corporate income tax. Mexico began to demand a larger share of the revenue generated by the maquiladoras. In response, it changed its trade policies and joined the General Agreement on Tariffs and Trade in 1986 (now known as the World Trade Organization)(Revilla 2712). This marked the beginning of a comprehensive trade treaty 
between the U.S. and Mexico.

Mexico's transition to becoming a global economy was evidenced by its entry into the OECD in 1994, and the signing of several treaties to avoid double taxation. In order to meet the obligations and responsibilities in entering these organizations, Mexico needed to adopt standard criteria for determining transfer prices. Mexico based its regulations on the premise that a Mexican corporation is organized as a profit-making entity. Mexico amended its Income Tax Laws (ITL) and required the maquiladoras that manufactured for related parties to charge at arm's length for their services. In essence, this meant that the operations had to cease to be cost centers and became profit centers. Although the amendments were passed in 1992, they did not become effective January 1, 1995 and the maquiladoras were chosen as the sector to implement transfer pricing.

The following example demonstrates the difference in taxation as a cost center and as a profit center (Gonzalez-Bendiksen 1):

Total Sales

Maquiladora costs

Maquiladora profit

U.S. Costs

Total Costs

U.S. Profit

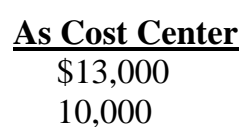

100

$\underline{1,000}$

11,100

$\$ 1,900$

As Profit Center
$\$ 13,000$
10,000
500
$\underline{1,000}$
11,500
$\underline{1,500}$

Income Tax Due:

Mexico@34\%

US@35\%

Total Tax
$\$ 34$

$\underline{665}$

$\$ \frac{669}{669}$
$\$ 170$

$\underline{525}$

$\underline{695}$

As the example illustrates, the overall financial impact of the change to profit center is minimal but the profits and subsequent tax revenues shifts from the United States to Mexico. Excluding any limitations imposed by the U. S. tax laws, income taxes paid in Mexico by the maquiladoras should generally qualify for foreign tax credit for the U.S. entity (IRC Sec 164, US-Mexican tax treaty Article 24).

\section{Transfer Pricing: Two Options to Meet Arm's Length Requirement}

Transfer prices are the prices, compensation amounts, or profit margins established in operations between related parties operating in different fiscal jurisdictions. Under the Mexican Income Tax Law (MITL), maquiladoras are required to charge at arm's length for their maquila activity, and keep careful and exact documentation to support the charges. Item 3.33.1 of the General Rules issued March 21, 1997 allowed the maquiladoras to choose one of two options to comply with the arm's length requirements (Gonzalez-Bendiksen 37).

The first option provides a "safe harbor" choice, which is a commitment by the maquiladora that the transfer pricing policy it adoptes will result in taxable income equal to or in excess of a specified threshold. Under this option, maquiladoras are deemed to have complied with arm's length prices if they generate a taxable profit for the tax year equal to or greater than 5\% of the value of all assets used in the maquila activity (Gonzalez-Bendiksen 38). The Assets Tax Law provides rules for calculating the tax. This option is advantageous to labor-intensive operations that havefew fixed assets.

The second option, an Advance Pricing Agreement (APA), can be used when the maquiladoras expected their taxable profit to be less than 5\% of the value of assets used in their operation (Gonzalez-Bendiksen 3). A request is filed with the Hacienda (Mexico's Ministry of the Treasury) to determine if the prices the maquilas calculate 
for transfer pricing are deemed to be at arm's length. Once an APA is approved, the maquiladoras are determined to be in compliance with the transfer pricing provisions. This option is preferable for capital-intensive operations.

\section{Compliance with Advance Pricing Agreements}

If the second option is chosen, maquiladoras are required to perform transfer-pricing studies to establish arm's length prices and to support their findings with documentation. Failure to comply with transfer pricing could result in the recomputation of prices charged for the activity. The resulting "new" profits are taxable income subject to the general $34 \%$ tax rate, adjusted for inflation from the month it should have been paid to the month it was actually paid. The tax is further subject to interest for up to ten years and a penalty of up to $160 \%$ of the tax as adjusted for inflation (Gonzalez-Bendiksen 38). Any penalty that resultes from an incorrect transfer pricing can be reduced by one-half, provided a transfer study has been performed and is supported by documentation (GonzalezBendiksen 38).

\section{Asset Tax Law}

One provision of the Asset Tax Law required all foreign principals to pay an additional tax equal to $1.8 \%$ of all assets used by the maquiladora (financial assets, fixed assets, intangibles and inventories). Under the USMexico tax treaty, if the maquiladoras did not create a permanent establishment in Mexico for the U.S. principal, inventory would be excluded from the calculation (Gonzalez-Bendiksen 38). If the nonresident principal lived up to the election made under the General Rules for transfer pricing, they were exempted from the asset tax, except for a percentage of its production intended for Mexican markets. In other words, if $20 \%$ of the maquiladora's production was intended for Mexican markets, only $80 \%$ of the exemption would apply. If the maquiladora did not live up to its election, the nonresident principal and the maquiladora were held jointly liable.

Nonresidents' Mexican income tax could be credited against the asset tax but the asset tax was not creditable as a foreign tax credit against U.S. federal income tax. The asset tax could be offset with Mexican income tax and the income tax would qualify as a foreign tax credit. For this reason, it was important for the nonresident principal to give careful attention to possible means of generating Mexican income tax to offset the asset tax, thus benefiting from the tax treaty.

\section{Mexican-US Tax Treaty}

Transfer pricing determines the country in which profit is recognized and in which the tax is imposed. For this reason, the IRS and the foreign tax authority are in opposition. Both Mexico and the Internal Revenue Service have the power to adjust transfer pricing to the extent that the transactions are not at arm's length. (IRC §482). Because the volume of transactions is frequently large, the adjustments are frequently large. In addition, the U.S. may impose penalties that can be as much as $40 \%$ of the adjustment (Tax Treaties 1). Double taxation may arise when the related party has computed its taxable income and paid tax on the basis of an actual (unadjusted) transfer price. In order to avoid double taxation, the adjustment must be withdrawn or the other tax authority must agree to a corresponding adjustment. Conflicts could lead to double taxation but international agreements provide a way to either avoid or to resolve conflicts.

The United States and Mexico signed the "Convention between the government of the United States of America and the government of the United Mexican States for the avoidance of double taxation and the prevention of fiscal evasion with respect to taxes on income" (hear after referred to as the double taxation treaty) in 1992 but it was not enacted until 1994 (Revilla 2711). Article 27 of the treaty authorizes "competent authorities" (CA) of each nation to assist in avoiding double taxation by agreeing on the allocation of income between the related parties. The CA agreement requires the adjusting country to reduce its adjustment and requires the other country to provide a corresponding adjustment. 


\section{Permanent Establishment}

Article 5 of the 1992 double taxation treaty allows Mexico to treat a maquiladora as a permanent establishment of the U.S. related party, if it fails to act as in independent agent (Convention 4,5). The Mexico ITL addressed the permanent establishment issue in 1994 when Article 2 was adopted. Paragraph 5 provides that no permanent establishment would be established in Mexico if the foreign party demonstrates that he acts in accordance with the principles of arm's length (Revilla 2711). If the maquiladora complies with arm's length or elects and complies with the safe harbor, no permanent establishment is deemed to exist. Article 2, paragraph 5 was replaced with a transitory provision in 1997 that maintained the exception but only for maquiladoras (Gonzalez-Bendiksen $37)$.

\section{Introduction of NAFTA}

The North American Free Trade Agreement (NAFTA) came into effect on January 1, 1994. The agreement established special preferential tariff treatment for goods "originating" in and traded among the NAFTA countries, Mexico, Canada and the US. NAFTA contained three provisions that were particularly significant to the maquiladoras (Fuller-Jacobs 22):

- In order to receive preferential tariffs, a minimum of $50 \%$ of most products' content had to come from one of the NAFTA countries.

- $\quad$ NAFTA provided for the eventual reduction of tariffs to zero for products that contain sufficient North American content.

- $\quad$ Special import and tariff provisions, such as those of the maquilas, were required to be phased out by 2001.

The maquiladoras were uncertain how NAFTA would affect the trade advantages they currently enjoyed. Ironically, the content requirements and tariffs reductions made them even more competitive under NAFTA. Content requirements favored North American manufacturers and Mexico was the most cost-effective place to locate new manufacturing companies. Although U.S. and Mexican tariffs were to be phased out, many Mexican tariffs were still significant when NAFTA was implemented. Thus, maquiladoras continued to benefit from duty-free imports into the country as provided by the maquila laws.

During the inception of the maquiladora program, the companies were allowed to sell up to $20 \%$ of their annual output in the Mexican domestic market, as long as they did not directly compete with an established industry (Jacobs-Fuller 22). The provision was expanded to up to 50\% in 1989. Under NAFTA, maquiladoras would eventually be permitted to sell up to $100 \%$ of their product in the Mexican domestic market. An increase in the allowance would greatly expand the market opportunities for U.S. manufacturers.

\section{Permanent Establishment Revisited}

Two legal instruments regulate the taxation of a U.S. resident abroad in Mexico, Mexico's Income Tax and the Mexico-U.S. double taxation agreement. As mentioned previously, Mexico had replaced Article 2 of its ITL with a transitory provision preserving the exemption of maquiladoras as permanent establishments. In December 1998, Mexico derogated the transitory provision, thus making very real the possibility of taxing the profits from the maquiladoras as permanent establishments (Revilla 2712). The ruling would require the maquiladoras to pay Mexican income taxes on the share of their income derived in Mexico and an additional 1.8\% asset tax on their machinery, equipment and inventories (Gerber 1).

The definition of a permanent establishment and the criteria for its creation are somewhat different in each of the two relevant documents. The ITL Article 2, II 1 and Article 5 of the tax agreement are similar in some aspects of the definition. Both definitions include "a fixed place of business through which the business of an enterprise is wholly or partly carried on." However, both go further in listing other criteria that can result in the creation of a permanent establishment (Revilla 2713-2716). 
abroad:

The ITL lists three different scenarios that might result in permanent establishment status: If the resident

- $\quad$ has a place of business in national territory

- $\quad$ acts through a dependent agent if it has powers to conclude contracts on behalf of the resident abroad

- $\quad$ acts through an independent agent which acts outside its ordinary course of business

The double taxation treaty lists only two cases that might result in permanent establishment:

- $\quad$ there is a fixed place of business

- $\quad$ if the resident abroad acts through a dependent agent

The "fixed place of business" is provided for in both instruments. This is not applicable in the typical maquiladora case, as most U.S. companies do not have a fixed place of business in Mexico. It could, however, result in permanent establishment status if the resident abroad owns assets located in Mexico. The "independent agent" does not create a permanent establishment as long as he acts within his ordinary course of business and adheres to the arm's-length principle. According to the ITL definition and the tax treaty, a "dependent agent" must have the power to conclude contracts of behalf of the resident abroad to create a permanent establishment. Article 5, I5 contains authorization that a dependent agent may create a permanent establishment with no power of attorney in specific situations. Mexico has never incorporated the authorization into the ITL because Mexican legislation in force requires that a dependent agent must have power of attorney.

The importance of permanent establishment status lies in the potential for double taxation. If the maquiladoras were found to be permanent establishments, Mexico federal tax authorities would have the power to tax the business profits. The firms would pay taxes on income derived from their Mexican operations, and then face a tax liability for the same income in the U.S. U.S. corporations would not receive a foreign tax credit from the Internal Revenue Service for taxes paid in Mexico. IRC Regulation 1.863-3 provides that income obtained through and attributable to a permanent establishment that produces goods that will be sold to clients in the US is not considered as being obtained from a foreign source of wealth and will not, therefore, be credited against the US income tax. Layering the Mexican corporate tax rate of $35 \%$ on top of the current U.S. business tax rate of $35 \%$ could result in an approximate $70 \%$ total taxation on the entire portion of US manufacturer's earnings (Mexican Tax Revision 12).

\section{Compromise}

After an intense lobbying effort on the part of U.S. businesses, the Mexican Finance Ministry and the IRS agreed on an alternative arrangement on Oct. 29, 1999. Under the new arrangement, effective January 1, 2000, permanent establishment status would be eliminated when maquiladoras follow one of two options (Rendon 2S103).

- The first option is a new Safe Harbor test wherein the taxable income of the maquiladora must be at least the higher of:

> $6.9 \%$ of the value of the assets used in the maquiladora in Mexico, including fixed assets and inventories owned by the U.S. parent, or

$>6.5 \%$ of the ordinary maquiladora deductions

- $\quad$ The second option is a modified advance pricing agreement taking into account the assets and inventories owned and used by the U.S. parent.

Under the first option, Mexico would tax the maquiladora at the corporate rate of $35 \%$ over the higher of either $6.9 \%$ of all assets used in production processes (including assets provided and placed in Mexico by the U.S. company), or $6.5 \%$ of all deductible expenses. This would include all expenses deductible under Mexican accounting laws, such as labor, insurance, transportation, utilities, and rent. The applicable percentage in either case represented a slight increase over the previous transfer-pricing formula of 5\% of assets used in the activity. 
Under the Advance Pricing Agreement, the maquiladoras would negotiate an up-front contract with the Mexican government for the payment of taxes. Although APSs already existed under the earlier transfer-pricing agreement, companies were required to either negotiate a new one or comply with the Safe Harbor formula.

If maquiladoras complied with the new transfer-pricing rules, they would qualify for an asset tax waiver on the foreign-owned assets used in the operations, provided no sales were made into the Mexican market. If they complied with the new rules but made sales into the Mexican market, they had to compute the assets tax on foreignowned assets on a proportionate basis, using total output and the portion sold in Mexico (Coronado 44). Because the new provisions are set to expire December 31, 2002, they are considered by many to be only temporary solutions.

\section{New Issues}

Mexico and the U.S. have signed an addendum to the October 1999 agreement in which they both agree to extend the existing rules indefinitely beyond 2002 (McLees \& Gonzalez-Bendiksen 1191). The addendum contains two circumstances in which the governments might agree to modify the rules after the end of 2002:

- $\quad$ Either may request that the $6.5 \& 6.9 \%$ rates established in the safe harbor threshold be reviewed and adjusted as based on new facts and circumstances.

- If the OECD issues guidelines for attributing income to a PE arising from a manufacturing operation, then either government may notify the other that it intends to terminate the intergovernmental agreement. This is based on the conclusion that the OECD guidelines would provide adequate practical rules for attributing income to a PE arising from a U.S. company's participation in the maquiladora program.

On June 30, 2000, Mexico issued amendments to the 2000 regulations. Of particular concern to U.S. companies is the failure of Mexico to preserve the asset tax and permanent establishment exemption for maquiladoras that comply with regulations after an audit adjustment or after a determination that it failed to supply all necessary documentation required by the regulations. The new regulations permit automatic forfeiture of the exemptions for anything more than a 5\% audit adjustment for a tax year (McLees and Gonzalez-Bendiksen 254). The loss of exemption applies even if that maquiladora later complies with the law by paying the adjusted tax liability and all adjustments, interest and penalties. Also, any determination that the maquiladora has failed to comply completely with the complex documentations required under the new regulations will result in the automatic loss of both the permanent establishment exemption and the asset tax exemption. U.S. companies are strongly objecting to these new rules, stating that the documentation requirements are so complex that even the most diligent attempts to comply may still in insufficient.

Mexico has also released notice that it will require higher markups than it has in the past as a condition for issuing APAs for 1999 and prior years. The increases are generally between 1-2 percentage points. In the past, cost markups were generally in the range of 4-7\%. Now it appears that Mexico has decided to require a minimum markup of 6.5\% in all maquiladora APAs (McLees and Gonzalez-Bendiksen 255). It is not yet certain that the U.S. will allow U.S. companies a full deduction for markups based on such minimums. Maquiladoras will be under pressure to accept the APAs as a condition for preserving the U.S. Company's exemptions from Mexican tax.

\section{Sectoral Programs.}

As NAFTA regulations deadlines draw near, Mexico is attempting to ease its transition and increase its competitiveness in key industries by establishing "sectoral programs". The programs, administered by Secofi (Mexico's Secretariat of Trade and Industrial development), provide for lower duty rates for foreign components used in certain industries. Registered producers are allowed to import non-NAFTA-originating goods that qualify under Tariff Schedules subject to an ad valorem tariff indicated in the specific sectoral program (Neville, Peterson \& Williams 12). The duty rates may be as low as zero and the highest rate will be $5 \%$ ad valorem. If an input qualifies under a sectoral program, it will be assessed a reduced duty rate when imported. As a result, a minimum or even zero duty will have to be paid when the qualifying finished product is exported to the U.S. or Canada. Sectoral pro- 
grams have been created for the electronics and automotive industries and others are likely to follow. It is not yet determined if these preferences are a violation of NAFTA.

\section{NAFTA - Seven Years Later}

The most profound impact of NAFTA directly affecting maquiladoras became effective January 1, 2001. Maquiladoras have always benefited from the waiver of Mexican import duties on imported materials, parts and components for use in the manufacture of finished products for export. They also currently have the additional benefit of preferential rates of duty upon importation of their finished products into the U.S. and Canada, provided they meet NAFTA rules of origin. However, under NAFTA Article 303, tariff breaks formerly given on all imported parts, supplies and equipment used in maquila factories will now apply only to such inputs from Canada, Mexico and the U. (Angulo-Parra \& Elias-Gernandez 1).

Maquiladoras have been permitted to import materials used in the production of finished products for export without incurring Mexican import duties. If the materials were imported permanently, rather than temporarily, they were then subject to import duties and other applicable taxes. Under the maquiladora program, only if finished products were sold in the domestic market were the maquiladoras required to pay import duties on the imported materials used in the production of the finished products. Article 303 of NAFTA mandates that as of January 1, 2001, if the finished products are exported to the U.S. or Canada, duty relief is only available on the non-NAFTA origin materials imported into Mexico if the finished product is subject to import duties upon importation in the U.S. or Canada (Argulo-Parra 1). Simply put, the maquiladora will be required to pay the difference between the Mexican import duties normally payable on the non-NAFTA origin materials and the U.S. or Canadian import duties payable on the finished product. Since duty rates on goods imported from Mexico into the U.S. and Canada are to be entirely phased out, no duty relief will be available on materials used in the production of the finished good if the finished good is NAFTA originating.

To illustrate under three different scenarios (Angulo-Parra and Elias-Gernandez 2), assume a maquiladora imported materials from Japan (a non-NAFTA country), valued at US $\$ 100$ for use in the manufacture of a finished product. The normal Mexican duty rate is $15 \%$, or $\$ 15$. The finished product, valued at $\$ 200$, is exported to the U.S., and does not qualify for NAFTA preferential duty rates. Assume it is subject to a tariff rate of $10 \%$, for a total of \$20. Under Article 303, Mexico may waive import duties on the materials equal to the lesser of:

- $\quad$ Mexican import duties payable on the materials $(\$ 15)$

- $\quad$ US import duties on the finished product $(\$ 20)$

Under this set of facts, Mexico can continue to waive the fully amount of import duties on the materials.

For the second example, assume the rate on import into the U.S. were 5\%, rather than $10 \%$ (\$10). Mexico could only waive import duties up to $\$ 10$. The importer of the goods into Mexico would have to pay the $\$ 5$ import duties at the time the finished product is exported to the U.S. Thirdly, assume the finished product complies with NAFTA rules of origin and NAFTA rates have been phased out entirely, Mexico cannot waive import duties on the materials and the importer of the material into Mexico would have to pay the full amount of duties normally payable on the materials at the time the finished good is exported to the U.S. (Angulo-Parra and Elias-Fernandez 3).

To summarize Article 303, a maquiladora will not pay Mexican import duties at the time of importation of materials into Mexico. However, it may be required to pay all or a portion of the Mexican import duties normally applicable at the time the finished product is exported to the U.S. or Canada, if the materials are not NAFTA originating. Generally, no duty relief will be available since, under NAFTA, duty rates on goods imported from Mexico to the U.S. and Canada will be phased out entirely. Maquiladoras exporting outside the U.S. and Canada will not be affected by this provision of NAFTA.

Mexico agreed to these restrictions in 1993 when negotiations for NAFTA were finalized and the country was given a seven-year grace period to prepare for implementation. Mexico did not publish the new rules, however, 
until November 2000. A Certificate of Origin documenting the origin of the inputs is required to qualify for tariff relief under the new rules. Many U.S. companies are unfamiliar with the form and the procedures necessary to ensure compliance. A large portion of U.S. companies wrongly believes that products produced in the U.S., Canada or Mexico automatically qualify for NAFTA treatment. The companies are unaware of the need to determine whether there are any foreign parts, components or raw materials used to manufacture the final product (Queen 1). (Copy attached in appendix)

\section{Issues Pending}

There are still many issues that have not been fully resolved and are subject to changes that may have a profound effect on both the maquiladoras and the related U.S. Company. New trade rules brought about by Article 303 of NAFTA, effective January 1, 2001, require Mexico to charge import duties on machinery and equipment temporarily imported from any non-NAFTA area. The requirement was based on the assumption that Mexico would be capable of competitively producing needed inputs for its export sector by that time. Mexico has not yet been successful in achieving this goal. The effect of Article 303 has been to reduce the ability of the maquiladoras to be competitive by increasing the costs of all non-NAFTA components and productive assets.

Another issue of which U.S. companies should be aware is that of new VAT (Value Added Tax) rules. Under current Mexican import laws, maquiladoras are currently exempt from VAT for machinery and equipment temporarily imported into Mexico. Companies that own the equipment are allowed an exemption from VAT if the equipment is temporarily imported. The equipment must be removed within five years or its Mexican depreciable life or it will be considered to be definitively imported and will then be imposed full VAT. Substantially more VAT may be ultimately imposed on temporarily imported machinery and equipment than would have been imposed had it initially been definitively imported. U.S. companies are currently allowed to provide the equipment on free bailment to maquiladoras. The implication is that as the overall production processes of maquiladoras become less competitive and generate fewer revenues, Mexico may attempt to restructure the rules in this area.

Although Mexico and the U.S. have signed an addendum to the agreement governing taxation of maquiladoras that preserves the exemptions from Mexican asset tax and permanent establishment, there exists the possibility of modifying the agreement with advance notice to taxpayers in 2003 . The addendum also provides the opportunity for either party to request a change in the percentages in the safe harbor formula after 2002.

Other areas of concern that are beyond the scope of this paper but will require a watchful eye include:

- $\quad$ Including leased assets in the $6.9 \%$ percent-of-asset-value base for the safe harbor calculations

- Valuation methods for inventory and assets that inflate the asset base

- Including cost of inventory in the cost base for the 6.5 percent-of-operating-costs calculation

- $\quad$ Preservation of the choice between the safe harbor and the APA

- $\quad$ Ambiguous rules for compliance with regulations for maintaining asset tax and permanent establishment tax exemptions for the U.S. companies.

\section{Future for the Maquiladoras}

The maquiladora activities have become a vital part of Mexico's economy. In 2000, there were more than 4000 of these operations with more than one million employees. The operations account for more than one-half of all of Mexico's exports and their combined output in 2000 was in excess of $\$ 83$ billion (Lucentini 4). The goods produced in the maquiladoras make up $80 \%$ of the exchange with the U.S., the industry's largest trading partner (Lindquist 23). In spite of these facts, the industry may be reaching a day of reckoning.

Under Article 303 of NAFTA, tariff relief is no longer available or is very limited to non-NAFTA countries importing to Mexico. To compound the negative effects of Article 303, other countries such as Malaysia and China are beginning to offer advantages to foreign companies, including lower wages, tax incentives, better infrastructure and less red tape. One of Mexico's biggest draws in the past has been the weakened peso and the resulting low la- 
bor rates. In the last two years, Mexican wages have been rising faster than inflation due, in part, to the strengthened peso and the result has been an increase in production costs (Smith 30).

It appears that Mexico is caught in a struggle between the need to generate revenues and the need to foster industrial development. The sectoral programs instituted to attract non-NAFTA countries have so far been successful in accomplishing its intent, but it has also had the undesirable result of decreasing revenues.

An important issue Mexico will need to address in the near future is that of upgrading the skills of its labor force. In the annual Global Competitiveness Report compiled by the Center for International Development at Harvard University, Mexico ranked 42 out of 58 countries (Smith 30). Yet Mexico refuses to offer tax breaks or other incentives to compensate for the quality of its workforce. As the costs of the workforce increases, so should the skill level?

Mexico needs to take a close look at the maquila industry as competition from other countries increases. Ireland and China, for instance, offer income tax rates of around 10-15\%, compared to Mexico's $35 \%$ tax rate. Some of the original industries to use the maquiladoras have already begun to shift operations to other countries that are offering more and better incentives. The electronics industry, a main user of maquiladoras, decreased its Mexican exports by $16 \%$ in the first quarter of 2001 and 15,000 jobs were lost in the industry in the first half of the year (Smith 30). Although overall foreign investment in Mexico has grown in 2001, it has decreased 23.3\% for the maquiladora operations (Lindquist $\mathrm{H}-1$ ).

Rising costs and decreased sales in the United States have caused many of the maquila industries to close their doors (Lindquist H-1). Mexico must take a hard look at the maquiladora industry's ability to compete with other countries and adjust accordingly. Both the economy and the citizens of Mexico have become too dependent on the opportunities the maquiladoras have brought over the last thirty years to do nothing but wait for its demise.

\section{Future for Related U.S. Companies}

Many of the advantages that originally attracted U.S. companies to the maquiladoras have either eroded or disappeared completely. As compliance rules become more difficult to interpret and administrative costs for compliance escalate, the maquila arrangement becomes less attractive to U.S. companies. Approval of Advance Pricing Agreements is currently lagging 6-12 months behind and the result could be exorbitant penalties for those companies found to be not in compliance.

Mexico's failure to document regulations past 2002 continues to be a problem for U.S. companies. New industries are hesitant to bring their operations to the maquiladoras and existing operations are beginning to explore other possibilities. These failures, coupled with the uncertainties of pending issues discussed earlier, have caused many U.S. companies to take a closer look at their current arrangements with the maquiladoras.

\section{Summary}

The Mexico-U.S. double taxation agreement grants U.S. companies exemption from both Mexican asset tax and permanent establishment status as a direct result of its relationship with a maquiladora, provided it complies with certain agreed standards for transfer pricing or taxable income. The U.S. agrees to allow a U.S. company deductions for payments made to a maquiladora for its processing services in an amount that meets the qualifications of "arm's-length" for transfer prices or its taxable income.

Key elements of the agreement are the standards the maquiladoras must meet to preserve the asset tax and permanent establishment exemptions for the U.S. companies. If the U.S. companies lose the permanent status exemption, they face the risk of exposure to both Mexican income tax and the asset tax. Loss of the PE exemption would enable Mexico to impose its 35\% tax rate on total profits realized through sales by U.S. companies of products manufactured in Mexico, and a potential of 1.8\% asset tax on all assets used in the maquila activities. Any Mexican incomes taxes required would not qualify for the foreign income tax credit under the IRS regulations. As a 
result, the maquiladoras would lose a major portion of its advantages offered to U.S. companies.

Since the Mexico-U.S. double taxation agreement's adoption in 1992, the standards applied in calculating transfer pricing have also changed. The safe harbor requirements have changed from 5\% of the value of all assets to $6.9 \%$ of the value of assets or $6.5 \%$ of all deductions allowed. The markup percentages required for obtaining an Advanced Pricing Agreement have also increased from $4-7 \%$ to a minimum of $6.5 \%$.

The original tax advantages and cost-efficiencies offered by the maquiladoras continue to erode. U.S. companies need to pay close attention to the pending issues discussed and the possible tax consequences. As competition for U.S. companies from other countries increase, the scales tip in favor of the United States. Mexico is too dependent on the revenues and employment opportunities offered by the maquiladoras to allow the industry to disappear.

\section{Bibliography}

1. “ABCs of Free-Trade Agreements." Dollars and Sense Jan 2001: 24.

2. Angulo-Parra, Carlos and Elias-Fernandez, Edmundo. "Mexico: Maquiladoras \& NAFTA Beyond Year 2000." (Online).

3. Aud, E., Cooper, R., Ackerman, B., Wood, K., Berger, H., and Danziger, E. "U.S. Transfer Pricing Developments in the Year 2000." Tax Notes International 22.1 (2001): 93-94.

4. Aud, E., Heimert, M., Ackerman, B., Wood, K., and Danziger, E. "Global Transfer Pricing Update - May 2001." Tax Notes International 22.20 (2001): 2487-2490.

5. Borkowski, Susan C. "Transfer Pricing Advance Pricing Agreements: Current Status by Country." International Tax Journal 26.2 (2000): 1-16.

6. Brouthers, Lane E. "Maquiladoras: Entrepreneurial Experimentation to Global Competitiveness." Business Horizons 42.2 (1999): 37-38.

7. Burns, Paul. "United States." International Tax Review 12.9 (2001): A103 (7).

8. "Convention between the Government of the United States of America and the Government of the United Mexican States for the Avoidance of Double Taxation and the Prevention of Fiscal Evasion with Respect to Taxes on Income." (Online) www.intltaxlaw.com/treaties/mexico/treaty.htm.

9. Coronado, Luis. "Mexico: US and Mexican Authorities Agree on Maquiladora Taxation." International Tax Review 11.2 (2000): 44-45.

10. Emert, Carol. "Mexico Hikes Maquiladora Tax but Most Dealers Won't Feel It." Home Furnishing_Network 69.9 (1995): 8.

11. Fuller-Jacobs, Nancy and Kiy, Richard. "Maquiladoras are Much Like Mini-Free Trade Agreements." San Diego Business Journal 12.20 (1991): 22.

12. Gerber, James. “Uncertainty \& Growth in Mexico’s Maquiladora Sector.” Borderlines 9.3 (2001): 1.

13. Gonzalez-Bendiksen, Jaime. "Maquiladora Transfer Pricing." (Online). www.natlaw.com/pubs/spmxcu6.htm.

14. $\quad$ Lindquist, Diane. "Rules Change for Maquiladoras." Industry Week, 250.1 (2001): 23.

15. Lindquist, Diane. "Maquiladora Mess; Factories Hit with Declining Sales, Higher Costs and Red Tape." The San Diego Union-Tribune, Oct. 28, 2001: H-1.

16. Lucentini, Jack. "Many Unprepared for Change in Maquiladora Rules." Journal of Commerce 9 Feb. 2000: World Trade 4.

17. "Maquila Taxes Business Mexico." American Chamber of Commerce of Mexico (2000).

18. Martinez, Hector. "Maquiladoras: Should US Companies Run for the Border?" (On-line). www.latinsynergy.org/maquiladoras.html.

19. McCosh, Daniel. "Maquiladoras Criticize Tax Changes." Journal of Commerce 17 Sep. 1999: World Trade 15.

20. MacKenzie, Narelle E. "Is it Time to Tune Up Your Maquiladora?" The Tax Adviser 31.4 (2000): 218219.

21. McLees, John A. and Gonzalez-Bendiksen, Jaime. "Changes in Mexican Tax Policies for Maquiladoras Leave Company Concerns Unresolved.” Tax Notes International 21.3 (2000): 251-262. 
22. McLees, John A. and Gonzalez-Bendiksen, Jaime. "Maquiladora Tax Issues Need Careful Attention as Mexico Extends the Current Maquiladora Tax Regime Beyond 2002." Tax Notes International 21.11 (2000): 1189-1195.

23. McLees, John and Gonzalez-Bendiksen, Jaime. "Maquiladora Tax Issues Still Need Careful Attention" Tax Notes 89.3 (2000): 409-414

24. McLees, John A., and Gonzalez-Bendiksen, Jaime. "Mexico Lags in Implementing Mutual Agreement on Maquiladora Taxation.” Tax Notes International 24.1 (2001): 2371-2382.

25. "Mexican Tax Revisions No Cause for Alarm." Apparel Industry Magazine 61.1 (2000): 12.

26. Neville, Peterson and Williams. "Mexico Facing New Era in 2001." Journal of Commerce 9 February 2000: 12 .

27. Pena, Horacio. "Transfer Pricing in Mexico." (On-line). www.pwcglobal.com/extweb/newcojou.nsf/DoclDManagement/E2F209732071B6238525662E005C008B

28. Queen, Joanne. "NAFTA Update: Frequently Asked Questions About the North American Free Trade Agreement." Trade Information Center, June 2001.

29. Rendon, Ruiz and Cia, Zamarripa y. "Mexico, Transfer Pricing Legislation." International Tax Review 12.9 (2001): A82(7).

30. Rendon, Ricardo and Cia, Zamarripa y. "Mexico." International Tax Review 11.2 (2000): 2 S103.

31. Reville, Eduardo and Alcala, Alil A. "Do Mexican Maquiladoras Really Constitute Permanent Establishments?" Tax Notes International_21.24 (2000): 2711-2718.

32. Sinclair, Bruce. "Maquiladoras 101." (On-line). www.cs.unb.ca/ alopez-o/politics/maq101.html.

33. Smith, Geri. "Is the Magic Fading?" Business Week 3744 (2001): 30.

34. Sowinski, Lara L. "Maquiladoras." World Trade 13.9 (2001): 93-94.

35. "Tax Treaties to the Rescue." (On-line). http://www.alston.com/docs/Articles/199709/30202104.htm.

36. Toro, Roberto del and Barrett, Fred. "Mexico." International Tax Review 09587594(Suppl.) (1999): 2731.

37. Zelenko, Laura. “Down Mexico Way.” Business North Carolina 12.11 (1992): 24(9). 